GEOLOGICAL SURVEY CIRCULAR 242

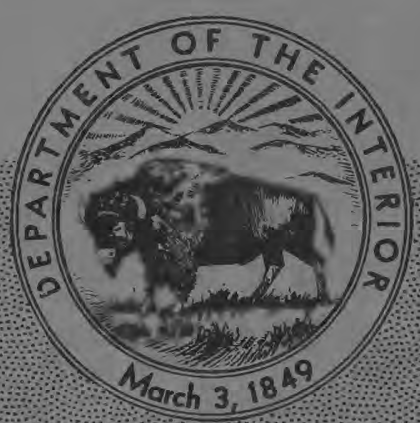

\title{
BIBLIOGRAPHY OF
}

U.S. GEOLOGICAL SURVEY

PUBLICATIONS ON

LEAD AND ZINC

By Gwendolyn W. Luttrell

(To January 1, 1953) 



\author{
UNITED STATES DEPARTMENT OF THE INTERIOR \\ Douglas McKay, Secretary \\ GEOLOGICAL SURVEY \\ W. E. Wrather, Director
}

GEOLOGICAL SURVEY CIRCULAR 242

\title{
BIBLIOGRAPHY OF U.S. GEOLOGICAL SURVEY PUBLICATIONS ON LEAD AND ZINC
}

By Gwendolyn W. Luttrell

(To January 1, 1953) 


\section{CONTENTS}

Scope and plan. .................... 1

Bibliography ........................ 1 Professional papers................. I

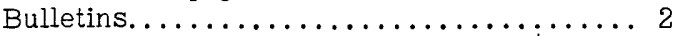

Monographs.........................6 6

Mineral resources of the United States..... . 6

Annual reports .................. 6

Folios of the Geologic Atlas of the

United States.................. 7
Bibliography--Continued

Circulars .................... 7

Preliminary reports and maps in open files.... 8

Preliminary reports and maps for

limited distribution................99

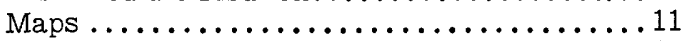

Miscellaneous publications.............11

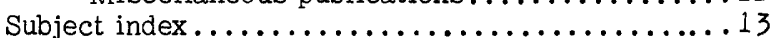

Author index .......................... 17 


.

$$
\cdot
$$




\title{
BIBLIOGRAPHY OF U.S. GEOLOGICAL SURVEY PUBLICATIONS
}

\author{
ON LEAD AND ZINC
}

SCOPE AND PLAN

This bibliography lists all publications on lead and zinc published by the Geological Survey prior to January 1, 1953. The reports are grouped by type of publication, such as professional papers, bulletins, monographs, and are numbered consecutively from 1 to 241 . These numbers are used to refer to the reports in the subject and author indexes at the end of the bibliography. The subject index lists the publications alphabetically by location and topic.

Unless otherwise indicated, publications for which prices are given can be purchased from the Superintendent of Documents, Government Printing Office, Washington 25, D. C. Those preceded by an asterisk (*) are out of print but can be seen in many public and university libraries.

\section{BIBLIOGRAPHY}

\section{Professional papers}

Index Prof.

no. Paper

(1) *21 The geology and ore deposits of the Bisbee quadrangle, Ariz. , by F. L. Ransome, 168 pp. , 1904.

(2) *24

(3) $\quad$ *26

(4) $\quad * 36$

(5) $\quad * 38$

(6) *62

(7) $\quad$ *63

(8) $\quad * 68$

(9) $\quad$ *74

(10) $\quad * 75$

(11) *77

(12) $* 80$

(13) $* 90$

(14) *94

(15) $* 96$

(16) $\quad * 97$

(17) $\quad * 107$

(18) $* 110$

(19) *111

(20) *138

Zinc and lead deposits of northern Arkansas, by G. I. Adams, assisted by A. H. Purdue and

E. F. Burchard, with a section on the determination and correlation of formations by

E. O. Ulrich, 118 pp. , 1904.

Economic resources of the northern Black Hills, by J. D. Irving, with contributions by

S. F. Emmons and T. A. Jagger, Jr., 222 pp. , 1904.

The lead, zinc, and fluorspar deposits of western Kentucky, by E. O. Ulrich and W. S. T. Smith, 218 pp. , 1905.

Economic geology of the Bingham mining district, Utah, by J. M. Boutwell, with a section on areal geology, by Arthur Keith, and an introduction on general geology, by S. F. Emmons, 413 pp. , 1905.

The geology and ore deposits of the Coeur d'Alene district, Idaho, by F. L. Ransome and F. C. Calkins, 203 pp., 1908.

Economic geology of the Georgetown quadrangle (together with the Empire district), Colo., by

J. E. Spurr and G. H. Garrey, with general geology, by S. H. Ball, 422 pp. , 1908.

The ore deposits of New Mexico, by Waldemar Lindgren, L. C. Graton, and C. H. Gordon, 361 pp. , 1910.

Geology and ore deposits of the Butte district, Mont., by W. H. Weed, 262 pp. , 1912.

Geology and ore deposits of the Breckenridge district, Colo. , by F. L. Ransome, 187 pp., 1911.

Geology and ore deposits of the Park City district, Utah, by J. M. Boutwell, with contributions by L. H. Woolsey, 231 pp. , 1912.

Geology and ore deposits of the San Francisco and adjacent districts, Utah, by B. S. Butler, 212 pp. , 1913.

Shorter contributions to general geology, 1914.

*(f) A reconnaissance in the Canyon Range, west-central Utah, by G. F. Loughlin, pp. $51-60,1915$.

Economic geology of Gilpin County and adjacent parts of Clear Creek and Boulder Counties, Colo. , by E. S. Bastin and J. M. Hill, 379 pp. , 1917.

The geology and ore deposits of Ely, Nev., by A. C. Spencer, 189 pp. , 1917.

Geology and ore deposits of the Mackay region, Idaho, by J. B. Umpleby, 129 pp. , 1917.

Geology and ore deposits of the Tintic mining district, Utah, by Waldemar Lindgren and G. F. Loughlin, with a historical review, by V. C. Heikes, 282 pp. , 1919.

A geologic reconnaissance of the Inyo Range and the eastern slope of the Sierra Nevada, Calif., by Adolph Knopf, with a section on the stratigraphy of the Inyo Range, by Edwin Kirk, 130 pp., 1918.

The ore deposits of Utah, by B. S. Butler, G. F. Loughlin, V. C. Heikes, and others, 672 pp., 1920.

Mining in Colorado, a history of discovery, development, and production, by C. W. Henderson, 263 pp. , 1926. 
(21) *139 Geology and ore deposits of the Ducktown mining district, Tenn., by W. H. Emmons and F. B. Laney, with the active collaboration of Arthur Keith, 114 pp. , 1926.

Geology and ore deposits of the Leadville mining district, Colo., by S. F. Emmons, J. D. Irving, and G. F. Loughlin, 368 pp. , 1927.

Geography, geology, and mineral resources of part of southeastern Idaho, by G. R. Mansfield, with descriptions of Carboniferous and Triassic fossils, by G. H. Girty, 453 pp. , 1927.

Geology and ore deposits of the Goodsprings quadrangle, Nev., by D. F. Hewett, 172 pp. , 1931. \$1. 15.

Geology and ore deposits of the Bonanza mining district, Colo., by W. S. Burbank, with a section on the history and production, by C. W. Henderson, 166 pp., 1932. $\$ 2$.

(27) *173 Geology and ore deposits of the Stockton and Fairfield quadrangles, Utah, by James Gilluly, 171 pp. , 1932.

Geology and ore deposits of the Breckenridge mining district, Colo., by T. S. Lovering, 64 pp. , 1934. \$1.

Geology and ore deposits of the Montezuma quadrangle, Colo., by T. S. Lovering, 119 pp., 1935.

Origin of the copper deposits of the Ducktown type in the southern Appalachian region, by C. S. Ross, 165 pp., 1935. $45 \mathrm{c}$.

The minerals of Franklin and Sterling Hill, Sussex County, N. J., by Charles Palache, 135 pp., 1937. $75 \mathrm{c}$.

Geology and ore deposits of the Magdalena mining district, N. Mex., by G. F. Loughlin and A. H. Koschmann, 168 pp., 1942(1943). $\$ 2$.

Geology and ore deposits of the Cottonwood-American Fork area, Utah, by F. C. Calkins and B. S. Butler, with sections on history and production, by V. C. Heikes, 152 pp., 1943.

Geology and ore deposits of the Metaline quadrangle, Wash., by C. F. Park, Jr., and R. S. Cannon, Jr., 81 pp., 1943. $\$ 1.50$.

219 Geology and ore deposits of the La Plata district, Colo., by E. B. Eckel, with sections by Geology and ore deposits of the La Plata district, Colo., by E. B. Eckel, with
J. S. Williams, F. W. Galbraith, and others, 179 pp., 1949(1950). $\$ 2.50$.

223 Geology and ore deposits of the Front Range, Colo., by T. S. Lovering and E. N. Goddard, 319 pp., 1950(1951). \$8.50. Plate 2 (geologic map of Front Range mineral belt) available separately! at $\$ 2$; plate 3 (map showing faults, veins, and mines), at $\$ 1.25$; plates 2 and 3 , at $\$ 3$ a set.

The disseminated lead ores of southeastern Missouri, by Arthur Winslow, 31 pp. , 1896.

Report on the economic geology of the Silverton quadrangle, Colo. , by F. L. Ransome, 265 pp. , 1901.

Contributions to economic geology, 1902.

Ore deposits of Bingham, Utah, by J. M. Boutwell, pp. 105-122, 1803.

Zinc and lead deposits of northern Arkansas, by G. I. Adams, pp. 187-196, 1903.

Lead and zinc deposits of the Joplin district, Mo. -Kans., by W. S. T. Smith, pp. 187-204, 1903.

Lead, zinc, and fluorspar deposits of western Kentucky, by E. O. Ulrich and W. S. T. Smith, pp. $205-213,1903$.

Zinc and manganese deposits of Franklin Furnace, N. J., by J. E. Wolff, pp. 214-217, 1903. Contributions to economic geology, 1903.

Progress report on the Park City mining district, Utah, by J. M. Boutwell, pp. 141-150, 1804. Lead and zinc deposits of Illinois, by H. F. Bain, pp. 202-207, 1904

Recent zinc mining in east Tennessee, by Arthur Keith, pp. 208-213, 1804.

Preliminary report on ore deposits of the Georgetown (Colo.) mining district, by J. E. Spurr and G. H. Garrey, pp. 99-120, 1905.

Lead and zinc resources of the United States, by H. F. Bain, pp. 251-273, 1905.

Ore deposits of the Coeur d'Alene district, Idaho, by F. L. Ransome, pp. 274-303, 1905.

Zinc and lead deposits of southwestern Wisconsin, by U. S. Grant, pp. 304-310, 1905. Zinc and lead mines near Dodgeville, Wis., by E. E. Ellis, pp. 311-315, 1905. 
Contributions to economic geology, 1905.

*(a) Gold and silver.

Economic features of northern Idaho and northwestern Montana, by D. F. MacDonald, pp. 41-52, 1906.

A reconnaissance of the mineral deposits of New Mexico, by WaldemarLindgren and L. C. Graton, pp. 74-86, 1906.

*(b) Copper.

Ore deposits in the St. Joe River basin, Idaho, by A. J. Collier, pp. 129-139, 1906.

*(d) Lead and zinc.

A Nevada zinc deposit, by H. F. Bain, pp. 166-169, 1906.

(45) 294

(46) $\quad * 320$

(47) $\quad * 340$

*347

$* 380$,

*384

*394

*397

$* 408$

$* 430$

*432

$* 450$

*451

$* 470$

Zinc and lead deposits of the upper Mississippi Valley, by H. F. Bain, 155 pp. , 1906. 75c.

The Downtown district of Leadville, Colo., by S. F. Emmons and J. D. Irving, 75 pp. , 1907. Contributions to economic geology, 1907. Part I.

*(a) The mineral deposits of the Cerbat Range, Black Mountains, and Grand Wash Cliffs, Mohave County, Ariz., by F. C. Schrader, pp. 53-83, 1908.

*(c) Mineral resources of northeastern Oklahoma, by C. E. Siebenthal, pp. 187-228; 1908. The Ketchikan and Wrangell mining districts, Alaska, by F. E. and C. W. Wright, 210 pp. , 1908. Contributions to economic geology, 1908. Part I.

*(c) The Tres Hermanas mining district, N. Mex., by Waldemar Lindgren, pp. 123-128, 1909.

A geological reconnaissance in northern Idaho and northwestern Montana, by F. C. Calkins, with notes on the economic geology, by D. F. MacDonald, 112 pp. , 1909.

Papers on the conservation of mineral resources (reprinted from report of the National Conservation Commission, February 1909), 214 pp., 1909.

Resources of the United States in gold, silver, copper, lead, and zinc, by Waldemar.Lindgren, pp. 114-156, 1909.

Mineral deposits of the Cerbat Range, Black Mountains, and Grand Wash Cliffs, Mohave County, Ariz. , by F. C. Schrader, 226 pp., 1909.

A reconnaissance of some mining camps in Elko, Lander, and Eureka Counties, Nev., by W. H. Emmons, 130 pp. , 1910.

Contributions to economic geology, 1909. Part I.

*(c) Notes on the mineral deposits of the Bearpaw Mountains, Mont. , by L. J. Pepperberg, pp. 135-146, 1910.

Some ore deposits in Maine and the Milan mine, N. H. , by W. H. Emmons, 62 pp. , 1910.

Mineral resources of the Llano-Burnet region, Tex., with an account of the pre-Cambrian geology, by Sidney Paige, 103 pp., 1911.

Reconnaissance of the ore deposits in northern Yuma County, Ariz. , by Howland Bancroft, 130 pp. , 1911.

Contributions to economic geology, 1910. Part I.

*(b) Geologic relation of ore deposits in the Elkhorn Mountains, Mont. , by R. W. Stone, pp. 75-98, 1911.

The ore deposits near Pinos Altos, N. Mex., by Sidney Paige, pp. 109-125, 1911.

*(d) Notes on lead and copper deposits in the Bear River Range, Idaho and Utah, by R. W. Richards, pp. 177-187, 1911.

Lead and zinc deposits in the Metaline mining district, northeastern Washington, by Howland Bancroft, pp. 188-200, 1911.

*478 Geology and ore deposits near Lake City, Colo. , by J. D. Irving and Howland Bancroft, 128 pp. 1911.

*480 Mineral resources of Alaska, report on progress of investigations in 1910.

*(c) Geologic features of Alaskan metalliferous lodes, by A. H. Brooks, pp. 43-93, 1911.

The mining districts of the western United States, by J. M. Hill, 309 pp. , 1912.

Ore deposits of the Helena mining region, Mont. , by Adolph Knopf, 143 pp. , 1913.

Geology and ore deposits of Lemhi County, Idaho, by J. B. Umpleby, 182 pp. , 1913.

The enrichment of sulphide ores, by W. H. Emmons, 260 pp. , 1913.

Contributions to economic geology, 1911. Part I.

*(e) A preliminary report on the geology and ore deposits of Creede, Colo. , by W. H. Emmons and E. S. Larsen, pp. 42-65, 1913.

*(g) A preliminary account of the ore deposits of the Loon Creek district, Idaho, by J. B. Umpleby, pp. 66-74, 1913.

Some ore deposits in northwestern Custer County, Idaho, by J. B. Umpleby, 104 pp. , 1913. 30c. Contributions to economic geology, 1912. Part I.

*(b) Mineral resources of the Inyo and White Mountains, Calif. , by Adolph Knopf, pp. $81-120,1914$.

*(e) Economic geology of the region around Mullan, Idaho, and Saltese, Mont. , by F. C. Calkins and E. L. Jones, Jr., pp. 167-211, 1914.

The lead-silver deposits of the Dome district, Idaho, by J. B. Umpleby, pp. 212-222, 1914. *(f) The Yellow Pine mining district,|Clark County, Nev., by J. M. Hill, pp. 223-274, 1914. 
Index

no.

(69) *580

$* 582$
$* 599$
$* 606$
$* 620$

The ore deposits of northeastern Washington, by Howland Bancroft, including a section on the Republic mining district, by Waldemar Lindgren and Howland Bancroft, 215 pp., 1914. Contributions to economic geology, 1913. Part I.

*(a) The Darwin silver-lead mining district, Calif., by Adolph Knopf, pp. 1-18, 1915 ,

*(c) Some cerusite deposits in Custer County, Colo., by J. F. Hunter, pp. 25-37, 1915.

*(k) Ore deposits in the Sawtooth quadrangle, Blaine and Custer Counties, Idaho, by J. B. Umpleby, pp. 221-249, 1915.

Mineral deposits of the Santa Rita and Patagonia Mountains, Ariz., by F. C. Schrader, with contributions by J. M. Hill, 373 pp., 1915.

Our mineral reserves-how to make America industrially independent, by G. O. Smith, 48 pp., 1914.

Origin of the zinc and lead deposits of the Joplin region, Missouri, Kansas, and Oklahoma, by

C. E. Siebenthal, 283 pp., 1915.

Contributions to economic geology, 1915. Part I.

*(h) A reconnaissance in the Kofa Mountains,Ariz. , by E. L. Jones, Jr., pp. 151-164, 1916.

*(i) A reconnaissance of the Cottonwood-A merican Fork mining region, Utah, by B. S. Butler and G. F. Loughlin, with notes on history and production, by V. C. Heikes, pp. 165-226, 1916.

*(m) Preliminary report on the economic geology of Gilpin County, Colo., by E. S. Bastin and J. M. Hill, pp. 295-323, 1916.

Useful minerals of the United States, compiled by F. C. Schrader, R. W. Stone, and

Samuel Sanford (a revision of Bulletin 585), 412 pp. , 1916.

The enrichment of ore deposits, by W. H. Emmons, 530 pp., 1917.

Contributions to economic geology, 1916. Part I.

*(a) Notes on the Promontory district, Utah, by B. S. Butler and V. C. Heikes, pp. 1-10, 1917.

*(b) Reconnais sance of the Conconully and Ruby mining districts, Wash., by E. L. Jones, Jr., pp. 11-36, 1917.

Notes on some mining districts in eastern Nevada, by J. M. Hill, 214 pp. , 1916.

Contributions to economic geology, 1917. Part I.

*(g) The Dunkleberg mining district, Granite County, Mont., by J. T. Pardee, pp. 241-247, 1918.

*(h) The antimonial silver-lead veins of the A rabia district, Nev., by Adolph Knopf, pp. 249-255, 1918.

Our mineral supplies, 1919.

(y) Zinc, by C. E. Siebenthal, 4 pp. $5 \mathrm{c}$.

(aa) Lead, by C. E. Siebenthal, $3 \mathrm{pp} .5 \mathrm{c}$.

Geology and mineral deposits of the Colville Indian Reservation, Wash., by J. T. Pardee, 186 pp., 1818.

The oxidized zinc ores of Leadville, Colo., by G. F. Loughlin, 91 pp., 1918. 20c.

Contributions to economic geology, 1918. Part I.

(a) Zinc carbonate and related copper carbonate ores at Ophir, Utah, by G. F. Loughlin, pp. 1-14, 1919. 5c.

Contributions to economic geology, 1919. Part I.

*(a) A reconnaissance of the Pine Creek district, Idaho, by E. L. Jones, Jr:, pp. 1-36, 1920.

Geology and ore deposits of the Creede district, Colo., by W. H. Emmons and E. S. Larsen, 198 pp. , 1923.

Contributions to economic geology, 1921. Part I.

*(h) Ore deposits of Cedar Mountain, Mineral County, Nev.*, by Adolph Knopf, pp. 361-382, 1922.

*(j) Ore deposits of the Sierrita Mountains, Pima County, Ariz., by F. L. Ransome, pp. 407-440, 1922.

Geology and ore deposits of Shoshone County, Idaho, by J. B. Umpleby and E. L. Jones, Jr., 156 pp. , 1923.

Mineral resources of Alaska, report on progress of investigations in 1921.

*(b) Mineral deposits of the Wrangell district, southeastern Alaska, by A. F. Buddington, pp. 51-75, 1923.

Geology and ore deposits of the Aravaipa and Stanley mining districts, Graham County, Ariz., by C. P. Ross, 120 pp., 1925.

The data of geochemistry (fifth edition), by F. W. Clarke, 841 pp., 1924.\$1. 75.

Ore deposits of the Saddle Mountain and Banner mining districts, Ariz., by C. P. Ross, 72 pp., 1925.

Guides to ore in the Leadville district, Colo., by G. F. Loughlin, 37 pp., 1926. 35c.

Contributions to economic geology, 1925. Part I.

*(a) The Melrose phosphate field, Mont. , by R. W. Richards and J. T. Pardee, pp. 1-32, 1926.

Ore deposits of the Jerome and Bradshaw Mountains quadrangles, Ariz., by Waldemar Lindgren, with statistical notes, by V. C. Heikes, 192 pp., 1926. 
Mineral resources of Alaska, report on progress of investigations in 1924.

*(d) The Nixon Fork country and silver-lead prospects near Ruby, by J. S. Brown, pp. 97-150, 1926.

Contributions to economic geology, 1926. Part I.

*(a) Recent developments in the Aspen district, Colo. , by Adolph Knopf, pp. 1-28, 1926.

Geology and mineral deposits of southeastern Alaska, by A. F. Buddington and Theodore Chapin, 398 pp. , 1929.

Geology of the DeQueen and Caddo Gap quadrangles, Ark, , by H. D. Miser and A. H. Purdue, 195 pp. , 1929.

Contributions to economic geology, 1929. Part I.

(a) The New World or Cooke City mining district, Park County, Mont. , by T. S. Lovering, pp. 1-87, 1930.

*(b) Recent mining developments in the Creede district, Colo., by E. S. Larsen, pp. 89-112, 1930. Geology and ore deposits of the Wood River region, Idaho, by J. B. Umpleby, L. G. Westgate, and C. P. Ross, with a description of the Minnie Moore and near-by mines, by D. F. Hewett, 250 pp. , 1930.

Contributions to economic geology, 1930. Part I. 50c.

(a) A graphic history of metal mining in Idaho, by C. P. Ross, pp. 1-9, 1931. 10c.

Microscopic determination of the ore minerals, by M. N. Short, 204 pp., 1931.

Metalliferous deposits of the greater Helena mining region, Mont., by J. T. Pardee and F. C. Schrader, 318 pp., 1933.

The miscroscopic determination of the nonopaque minerals (2d edition), by E. S. Larsen and Harry Berman, 266 pp. , 1934. 60c.

Investigations in Alaska Railroad belt, 1931.

(d) The Mount Eielson district, Alaska, by J. C. Reed, pp. 231-287, 1933(1934). 25 c.

Zinc and lead deposits of northern Arkansas, by E. T. McKnight, 311 pp. , 1935.

Geology and ore deposits of the Casto quadrangle, Idaho, by C. P. Ross, 135 pp. , 1934(1935).

Geology of the Santa Rita mining area, N. Mex., by A. C. Spencer and Sidney Paige, 78pp. , 1935.

Geology and ore deposits of the Bayard area, Central mining district, N. Mex., by S. G. Lasky, 144 pp. , 1936.

Mineral resources of the region around Boulder Dam, by D. F. Hewett, Eugene Callaghan,

B. N. Moore, T. B. Nolan, W. W. Rubey, and W. T. Schaller, 197 pp. , 1936.

Geology and mineral deposits of the Snowmass Mountain area, Gunnison County, Colo. , by

J. W. Vanderwilt, 184 pp. , 1938.

Geology and ore deposits of the Lordsburg mining district, Hidalgo County, N. Mex., by

S. G. Lasky, 62 pp. , 1938. \$1.25.

Geology and mineral resources of the Honeybrook and Phoenixville quadrangles, Pa., by

F. Bascom and G. W. Stose, 145 pp. , 1938.

Metalliferous mineral deposits of the Cascade Range in Oregon, by Eugene Callaghan and

A. F. Buddington, 141 pp., 1938. $\$ 1.25$.

Contributions to economic geology, 1938-39.

(d) Geology of the Searchlight district, Clark County, Nev., by Eugene Callaghan, pp. $135-188,1939$. 40c.

*(e) Structural control of ore deposition in the Uncompahgre district, Ouray County, Colo. , with suggestions for prospecting, by W. S. Burbank, pp. 189-265, 1940(1941).

Ore deposits in the vicinity of the London fault of Colorado, by Q. D. Singewald and B. S. Butler,

74 pp. , 1941. \$1.50.

Microscopic determination of the ore minerals (2d edition), by M. N. Short, 314 pp. , 1940. \$1.50.

Contributions to economic geology, 1941-42.

*(b) Geology and ore deposits of the Shafter mining district, Presidio County, Tex., by C. P. Ross, pp. 45-125, 1943.

Contributions to economic geology, 1943-44.

(b) Geology of the lead-silver deposits of the Clark Fork district, Bonner County, Idaho, by A. L. Anderson, pp. 37-117, 1947. 75c.

(c) Geology and ore deposits of Boise Basin, Idaho, by A. L. Anderson, pp. 119-319, $1947(1949)$. $\$ 2.25$.

Geology and ore deposits of the Libby quadrangle, Mont., by Russell Gibson, 131 pp., 1948. 55c Mineral resources of Alaska, 1945-46.

(a) Some mineral investigations in southeastern Alaska, by W. S. Twenhofel, J. C. Reed, and G. O. Gates, pp. 1-45, 1949. 40c.

Geologic investigations in the American republics, 1949.

(b) Mineral resources of Colombia (other than petroleum), by 6. D. Singewald, pp. 53-204, 1950. $\$ 1$. 
970 Geology and ore deposits of the upper Blue River area, Summit County, Colo. , by

Q. D. Singewald, 73 pp. , 1951(1952). \$1.75.

(123) 978 Contributions to economic geology, 1951

(d) Zinc-lead deposit at Shawangunk mine, Sullivan County, N. Y., by P. K. Sims and P. E. Hotz, pp. 101-121, 1951(1952). 60c.

(e) The Wallapai mining district, Cerbat Mountains, Mohave County, Ariz. , by M. G. Dings, pp. 123-163, 1951(1952). \$1.

(124) $998 \quad$ Zinc and lead deposits of southeastern Alaska.

(a) Zinc-copper deposits at Tracy Arm, Petersburg district, Alaska, by H. R. Gault and R. E. Fellows, 1953.

(b) Some zinc-lead deposits of the Wrangell district, Alaska, by H. R. Gault, D. L. Rossman, G. M. Flint, Jr., and R. G. Ray, 1953.

(c) Some zind-lead and zinc-copper deposits of the Ketchikan and Wales districts, Alaska, by G. D. Robinson and W. S. Twenhofel, 1953.

(125) 984 Geologic reconnaissance of the mineral deposits of Thailand, by G. F. Brown and others, 183 pp. , 1951(1952). \$2.50.

Index.

Monographs

no. Mon.

Silver-lead deposits of Eureka, Nev., by J. S, Curtis, 200 pp. , 1884.

Geology and mining industry of Leadville, Colo., with atlas, by S. F. Emmons, 770 pp. , 1886. Geology of the Eureka district, Nev. , by Arnold Hague, 419 pp. , 1892.

(129) $\quad * 31$

Geology of the Aspen mining district, Colo., with atlas, by J. E. Spurr, 260 pp. , 1898.

\section{Mineral Resources of the United States}

Production statistics and data on the technology of lead and zinc refining are contained in Mineral Resources of the United States, published annually by the Geological Survey until 1925. Only chapters containing information of special interest are listed below. In 1925 publication of the Mineral Resources volumes was transferred to the Bureau of Mines, and the title was changed to Minerals Yearbook in 1932. Annual editions of Minerals Yearbook can be purchased, if available, from the Superintendent of Documents, Government Printing Off ice, Washington $25, \mathrm{D}$. C.

Index

no.

*Mineral Resources of the United States, 1914. Part I.

*(f) Zinc, by C. E. Siebenthal: Resources (foreign), pp. 877-884, 1916.

Mineral Resources of the United States, 1915. Part I. \$1.

(k) Zinc, by C. E. Siebenthal: Resources by States and counties, with bibliography, pp. 859-924; Foreign deposits, pp. 925-943, 1917. 15c.

\section{Annual reports}

Index

no.

*Second Annual Report of the United States Geological Survey, 1880-81.

*(d) Abstract of report on geology and mining industry of Leadville, Lake County, Colo. , by S. F. Emmons, pp. 201-290, 1882.

*Fourth Annual Report of the United States Geological Survey, 1882-83.

*(c) Abstract of report on the mining geology of the Eureka district, Nev., by|J. S. Curtis, pp. 221-251, 1884.

*Seventeenth Annual Report of the United States Geological Survey, 1895-96.

*Part II.

*(c) The mines of Custer County, Colo., by S. F. Emmons, pp. 405-472, 1896.

*Eighteenth Annual Report of the United States Geological Survey, 1896-97.

*Part III.

*(f) Preliminary report on the mining industries of the Telluride quadrangle, Colorado, by C. W. Purington, pp. 745-850, 1898

*Nineteenth Annual Report of the United States Geological Survey, 1897-98.

*Part III.

*(f) Geology and mining industry of the Tintic district, Utah, by G. W. Tower, Tr., and G. O. Smith, pp. 601-767, 1899. 
*Twentieth Annual Report of the United States Geological Survey, 1898-99.

*Part III.

*(b) The gold and silver veins of Silver City, De Lamar, and other mining districts in Idaho, by Waldemar Lindgren, pp. 65-256, 1900.

*(c) Geology of the Little Belt Mountains, Mont. , with notes on the mineral deposits of the Neihart, Barker, Yogo, and other districts, by W. H. Weed, accompanied by report on the petrography of the igneous rocks of the district, by L. V. Pirsson, pp. $257-581,1900$.

*Twenty-second Annual Report of the United States Geological Survey, 1900-01.

*Part II.

*(b) Preliminary report on the lead and zinc deposits of the Ozark region, by H. F. Bain, with an introduction by C. R. Van Hise, and chapters on the physiography and geology by G. I. Adams, pp. 25-227, 1901.

*(c) The ore deposits of the Rico Mountains, Colo., by F. L. Ransome, pp. 229-398, 1901.

*(d) Geology and ore deposits of the Elkhorn mining district, Jefferson County, Mont., by W. H. Weed, with an appendix on the microscopical petrography of the district by Joseph Barrell, pp. 399-550, 1901.

*(f) The ore deposits of Monte Cristo, Wash., by J. E. Spurr, pp. 777-865, 1901.

Folios of the Geologic Atlas of the United States

Index

no.

(140)

(141)

(142)

(143)

(144)

(145)

(146)

(147)

(148)

(149)

(150)

(151)

(152)

(153)

(154)

(155)

(156)
Folio

$* 20$
$* 27$
$* 56$
$* 59$
$* 65$
$* 75$
$* 112$
$* 120$
$* 130$
$* 145$
$* 148$
$* 161$
$* 183$
$* 200$
$* 202$
$* 217$
$* 219$
222

Cleveland, Tenn., by C. W. Hayes, 5 pp. , 1895.

Morristown, Tenn., by Arthur Keith, 7 pp., 1886.

Little Belt Mountains, Mont., by W. H. Weed, 11 pp. , 1899.

Bristol, Va. -Tenn., by M. R. Campbell, 12 pp. , 1899.

Tintic special, Utah, by G. W. Tower, G. O. Smith, and S. F. Emmons, 8 pp., 1900.

Maynardville, Tenn., by Arthur Keith, 7 pp. , 1901.

Bisbee, Ariz. , by F. L. Ransome, 18 pp., 1904.

Silverton, Colo., by Whitman Cross, Ernest Howe, and F. L. Ransome, 35 pp. , 1905.

Rico, Colo., by Whitman Cross and F. L. Ransome, 21 pp. , 1905.

Lancaster-Mineral Point, Wis. -Iowa-Ill., by U. S. Grant and E. F. Burchard, 14 pp. , 1907.`

Joplin district, Mo. -Kans., by W. S. T. Smith and C. E. Siebenthal, 20 pp. , 1907.

Franklin Furnace, N. J., by A. C. Spencer, H. B. Kümmel, J. E. Wolff, R. D. Salisbury, and Charles Palache, 27 pp. , 1908.

Llano-Burnet, Tex., by Sidney Paige, 16 pp., 1812.

Galena-Elizabeth, Ill. -Iowa, by E. W. Shaw and A. C. Trowbridge, 13 pp. , 1916.

Eureka Springs-Harrison, Ark.-Mo., by A. H. Purdue and H. D. Miser, 22 pp. , 1916.

Ray, A riz. , by F. L. Ransome, 24 pp. , 1923.

Central Black Hills, S. Dak., by N. H. Darton and Sidney Paige, 35 pp. , 1925.

Gaffney-Kings Mountain, S. C. -N. C., by Arthur Keith and D. B. Sterrett. 13 pp., 1931. 50c.

\section{Circulars}

These publications may be obtained, if not out of print, on request to the U. S. Geological Survey, Washington 25, D. C.

Index

no.

(157)
Circ. $* 28$

41

131

161

168
Annotated bibliography of papers on geochemical prospecting for ores, by H. E. Hawkes, 6 leaves, 1948.

Field method for the determination of zinc in plants, by L. E. Reichen and H. W. Lakin, 4 pp., 1949.

Techniques used in mine-water problems of the east Tennessee zinc district, by D. F. Kent, $9 \mathrm{pp} ., 1950$.

Exploratory drilling in the Prairie du Chien group of the Wisconsin zinc-lead districts by the U. S. Geological Survey in 1949-1950, by A. V. Heyl, Jr. , E. J. Lyons, and A. F. Agnew, 35 pp. , 1952.

Compilation of field methods used in geochemical prospecting by the U. S. Geological Survey, by H. W. Lakin, Hy Almond, and F. N. Ward, 34 pp. , 1952.

Geochemical studies in the Coeur d'Alene mining district, Idaho, by V. C. Kennedy, 15 pp. , 3 illus. , 1952. 
These publications may be consulted at the U. S. Geological Survey Library, Room 1033, General Services Building, Washington, D. C., and also at the regional offices listed after each State.

Index

no.

Alaska

U. S. Geological Survey Office, Juneau, Alaska.

U. S. Geological Survey Office, Fairbanks, Alaska.

Preliminary report on a lead-zinc occurrence at Berg Basin, Wrangell district, southeastern Alaska, by R. G. Ray, 9 pp. , 4 maps, 1946.

A rizona

California

Colorado

Idaho

(173)

Iowa

Arizona Bureau of Mines, Tucson, Ariz.

Library, University of California, Los Angeles, Calif.

Geology of the Humboldt region and the Iron King mine, Bigbug mining district, Yavapai County, Ariz., by S. C. Creasey, 146 pp. , 18 illus., 1950.

U. S. Geological Survey, 102 Old Mint Building, 5th and Mission Sts., San Francisco, Calif. California State Division of Mines, Ferry Bldg. , San Francisco, Calif.

Geology of the Lippincott lead area, Inyo County, Calif., by J. F. McAllister, 10 pp. , 4 illus. , 1 geol. map, 1949.

U. S. Geological Survey Information Cffice, Room 468, New Customhouse, Denver, Colo.

Preliminary report on the geology and ore deposits of the Minturn quadrangle, Colo., by T. S. Lovering and O. L. Tweto, 115 pp. , 2 maps, 1944.

Suggestions for prospecting in the Silver Plume district, Clear Creek County, Colo., by E. N. Goddard, 6 pp. , 4 maps, 1944. (This report can also be seen at the U. S. Geological Survey Information Office, Room 506, Federal Bldg., Salt Lake City, Utah).

Map of the Kokomo (Tenmile) zinc-lead mining district, Colorado, by A. H. Koschmann and F. G. Wells, 1948.

U. S. Geological Survey diamond drill logs, Kokomo (Tenmile) zinc-lead mining district, Colorado, by A. H. Koschmann, 1 p. , 1 map, 1949.

Preliminary map of the geology of the area south of Telluride, Colo. , by J. S. Vhay, 1949. (This report can also be seen at the Public Library in Telluride, Colo.)

Geologic maps of lead-zinc mines, Kokomo district, Summit County, Colo. , by A. H. Koschmann, 12 maps, 1950.

Geologic maps of the Leadville drainage tunnel, Colorado, by O. L. Tweto, 11 maps, 1951. (This report can also be seen at the office of the State Commissioner of Mines, State Museum Building, Denver, Colo.)

Geologic map of the Garfield quadrangle, Colorado, by M. G. Dings, C. S. Robinson, and M. R. Brock, 1 list, 5 illus., 1952. (This report can also be seen at the U. S. Geological Survey Information Office, Room 506, Federal Building, Salt Lake City, Utah, and at the office of the State Commissioner of Mines, State Museum Building, Denver, Colo.)

U. S. Geological Survey Office, S. 157 Howard Street, Spokane, Wash.

Lead and zinc deposits of the Pine Creek area, Coeur d'Alene mining region, Shoshone County, Idaho, by J. D. Forrester and V. E. Nelson, 27 pp. , 7 maps, 1945.

Preliminary report on the geology of some mineral deposits in the Twin Crags area, Kootenai County, Idaho, by S. E. Good, 11 pp., 2 illus., 1949. (This report can also be seen at the Idaho Bureau of Mines and Geology, Moscow, Idaho.)

Geology of the southern third of the Mullan and Pottsville quadrangles, Shoshone County, Idaho, by S. W. Hobbs, R. E. Wallace, and A. B. Griggs, 24 pp. , 1 map, 1950.

Geologic map of the Pottsville quadrangle, northern Idaho, by R. E. Wallace and others, 1 map with overlay, 1952. (This report can also be seen at the Idaho Bureau of Mines and Geology, Moscow, Idaho, and at the U. S. Geological Survey Information Office, Room 506, Federal Building, Salt Lake City, Utah.)

Geologic maps of the north half of the Mullan and vicinity quadrangle, Idaho, by A. B. Griggs, 5 maps, 1952. (This report can also be seen at the Idaho Bureau of Mines and Geology, Moscow, Idaho, and U. S. Geological Survey offices at Room 506, Federal Building, Salt Lake City, Utah, and Room 468, New Customhouse, Denver, Colo.)

U. S. Geological Survey Office, Room 213, Science Hall, University of Wisconsin, Madison, Wis. U. S. Geological Survey Office, Wisconsin Institute of Technology, Platteville, Wis.

Office of the State Geologist, Iowa Geological Survey, Geology Annex, Iowa City, Iowa.

Description of rock formations and minerals from holes drilled in Tete des Morts area, Iowa, by A. F. Agnew, 22 pp. , 1952.

Nevada Bureau of Mines, Reno, Nev.

Geology of the Antler Peak quadrangle, Nev., by R. J. Roberts, 108 pp. , geol. map, 35 illus. , 1949. (This report can also be seen at the Sterling Memorial Library, Yale University, New Haven, Conn.)

Green Monster mine, Clark County, Nev., by A. L. Brokaw, 9 pp., 7 pls. , 1951. (This report can also be seen at the Geological Survey Distribution Office, Room 504, Federal Building, Salt Lake City, Utah, and at the Geological Survey, 102 Old Mint Building, San Francisco, Calif.) 
Preliminary report on the Rip Van Winkle mine, Elko County, Nev., by T. S. Lovering and W. C. Stoll, 9 pp., 7 figs., 1951. (This report can also be seen at the U. S. Geological Survey Distribution Office, Room 504, Federal Building, Salt Lake City, Utah.)

New Mexico (182)

North Carolina

Oklahoma

Tennessee

Texas

Utah

(190)

Washington

Wisconsin

Lead, zinc, and copper deposits of the Organ district, N. Mex., by C. C. Albritton, Ir., and V. E. Nelson, 39 pp. , 25 illus., 1943. (This report can also be seen at the U. -S. Geological Survey Information Office, Room 506, Federal Building, Salt Lake City, Utah.)

Geology and ore deposits of the Royal John area, Swartz district, N. Mex., by D. M. Kinney, 18 pp. , 3 maps, 1944.

New Placers mining district, San Pedro and Carnahan mines, Santa Fe County, N. Mex., by J. F. Smith, A. H. Wadsworth, J. R. Cooper, F. W. Farwell, and A. E. Weissenborn, 28 pp. , 14 maps, 1945.

U. S. Geological Survey Office, Room 220, Post Office Building, Asheville, N. C.

U. S. Geological Survey Office, Room 13, Post Office Building, Knoxville, Tenn.

Office of the State Geologist, State Department of Conservation and Development, Box 2719, Raleigh, N. C.

Redmond lead-zinc mine, Haywood County, N. C., by G. H. Espenshade, M. H. Staatz, and E. A. Brown, 7 pp. , 3 maps, 1947.

Office of the Director of the Oklahoma Geological Survey, Norman, Oklahoma.

Office of the Director of the Missouri Geological Survey, Box 250, Rolla, Mo.

Geologic map of the Wyandotte quadrangle, northeastern Oklahoma and southwestern Missouri, by C. E. Siebenthal and R. D. Mesler, 1950.

U. S. Geological Survey Office, Room 13, Post Office Building, Knoxville, Tenn.

Office of the State Geologist, State Office Building, Nashville 3, Tenn.

Stiner zinc prospect, Union County, Tennessee, by R. A. Laurence, Irvin Gladstone, V. E. Nelson, and D. F. Kent, 4 pp. , drill logs, 3 maps, 1946.

Diamond drill logs, Eve Mills zinc area, Monroe County, Tenn., by J. C. Dunlap, 106 pp. , 32 logs, 1952.

Office of the Postmaster, Marfa, Texas.

Geology and ore deposits of the western part of the Shafter district, Presidio County, Texas, by J. S. Cullison and A. E. Weissenborn, 21 pp. , 7 maps, 1944.

U. S. Geological Survey Information Office, Room 506, Federal Bldg., Salt Lake City, Utah.

Preliminary report on the Apex and Paymaster mines, Washington County, Utah, by A. R. Kinkel, Jr., 9 pp. , 13 figs. , 1951.

U. S. Geological Survey Office, S. 157 Howard Street, Spokane, Wash.

Lead Hill area on Slate Creek, Metaline district, Pend Oreille County, Wash. , by H. L. Tames and J. P. Albers, 13 pp., 5 illus., 1844.

Tom Cat and Hanley prospects, Metaline lead-zinc district, Pend Oreille County, Wash. , by C. D. Campbell and Irvin Gladstone, 18 pp. , 7 illus. , 1944.

Geology and ore deposits of the Carbo zine prospect, Northport district, Stevens County, Wash., by C. D. Campbell, 7 pp. , 2 maps, 1845.

Lead-zinc deposits in part of the Northport mining district, Wash., by C. D. Campbell, 6 maps, 1946. (This report can also be seen at the Washington Division of Mines and Geology, 420 Transportation Building, Olympia, Wash.)

Geology of the Bechtol lead mine, Northport district, Stevens County, Wash., by C. D. Campbell, 4 pp. , 2 maps, 1948. (This report can also be seen at the Washington Division of Mines and Geology, 420 Transportation Building, Olympia, Wash. )

Wisconsin Geological and Natural History Survey, Science Hall, University of Wisconsin, Madison, Wis.

The upper Mississippi Valley zinc district, by A. V. Heyl, Jr., 271 pp., 44 illus., 1950. (This report can also be seen at the Princeton University Library, Princeton, N. J.)

Lead and zinc deposits of the Beetown area, Wisconsin, by A. V. Heyl, Jr., E. T. Lyons, and J. J. Theiler, 17 pp. , 1 pl. , 1950. (This report can also be seen at the U. S. Geological Survey Office, Wisconsin Institute of Technology, Platteville, Wis.)

Description of rock formations and minerals from holes drilled in Highland area, Wisconsin, by A. E. Flint, 24 pp. , 1952. (This report can also be seen at the U. S. Geological Survey Office, Room 213, Science Hall, University of Wisconsin, Madison, Wis., and at the U. S. Geological Survey Office, Wisconsin Institute of Technolcisy, Platteville, Wis.)

\section{Preliminary reports and maps for limited distribution} Index

These publications may be obtained, if not out of print, on request to the U. S. Geological Survey, Washington 25, D. C. no. 
Zinc-copper deposits near Moth Bay, Revillagigedo Island, southeastern Alaska, by G. D. Robinson, 10 pp. , 3 maps, 1944.

Lead-zinc deposits at the Lake claims, Wrangell district, southeastern Alaska, by H. R. Gault and G. M. Flint, Jr., 6 pp. , 3 maps, 1944.

Zinc deposits of the Mt. Eielson district, Alaska, by G. O. Gates and Clyde Wahrhaftig, 10 pp. , 3 maps, 1944.

The zinc deposits of the Lucky Boy claims, Prince of Wales Island, southeastern Alaska, by W. S. Twenhofel, 3 pp. , 3 maps, 1944.

Geology and mineral deposits of Glacier Basin and vicinity, Wrangell district, southeastern Alaska, by H. R. Gault, D. L. Rossman, and G. M. Flint, Jr., 12 pp. , 2 maps, 1944.

*Copper and zinc deposits. in the Reward area, Pinal County, Ariz., by J. B. Hadley and H. H. Sullwold, Jr. , 7 maps, 1944:

*Geology and ore deposits of the Carbonate King mine, Koko Weef Mountain area, San Bernardino County, Calif., by A. R. Richards and A. L. Brokaw, 3 pp. , 4 maps, 1944.

Preliminary geologic map of Mosquito Range near Leadville, Colo., by C. H. Behre, Jr. , E. N. Goddard, and A. E. Sandburg, 29 pp., 1 map, 1948. \$1. from Distribution Section, U. S. Geological Survey, Denver Federal Center, Denver, Colo.

Lead and zinc deposits at Rico, Dolores County, Colo., by D. J. Varnes and A. H. Wadsworth, Tr., 4 maps, 1944.

Geologic maps of Uncompahgre (Ouray) district, Colo., by W. S. Burbank and M. G. Barclay, Strategic Minerals Investigations Preliminary Map 3-217, 2 maps, 1947.

*Zinc-lead mines of the Pine Creek area, Coeur d'Alene region, Shoshone County, Idaho, by J. D. Forrester, 12 maps, 1944.

Map of the surface geology of the Pine Creek area, Coeur d'Alene region, Shoshone County, Idaho, by V. E. Nelson, J. F. Smith, Jr., G. A. Duell, and R. M. Hutchinson, 1 map, $1944.60 \mathrm{c}$ from Chief of Distribution, U. S. Geological Survey, Washington 25, D. C.

Lead and zinc deposits of the Center Grove-Pikes Peak area, IDubuque County, Iowa, by A. V. Heyl, Jr., A. F. Agnew, C. H. Behre, Jr., and E. J. Lyons, Strategic Minerals Investigations Preliminary Map 3-203, 6 pp. , 1 map, 1946.

Carlisle area of the Steeple Rock mining district, Grant County, N. Mex., by R. T. Griggs and H. C. Wagner, 4 pp. , 4 maps, 1943.

The North mining area, Cerrillos district, Santa Fe County, N. Mex., by W. C. Stoll, Strategic Minerals Investigations Preliminary Map 3-205, 3 pp. , 2 maps, 1846.

*Diamond drilling in the West Branch area, Gouverneur district, N. Y. , by A. E. Engel, J. J. Page, and C. N. Bozion, Strategic Minerals Investigations Preliminary Map 3-222, 2 pp. 1 map, 1948.

Zinc-lead deposits in part of the Picher field, Ottawa County, Okla., and Cherokee County, Kans. , by E. T. McKnight, R. P. Fischer, C. C. Addison, K. R. Bowie, J. M. Thiel, M. F. Owens, Tr., and F. G. Wells, 1 map in 6 sheets, 1944. $\$ 2$. from Chief of Distribution, U. S. Geological Survey, Washington 25, D. C.

Copper Ridge zinc district, Eastern Tennessee, by John Rodgers, D. F. Kent, and R. M. Hutchinson, 5 maps with text, 1943. (Geologic map only available.)

Powell River zinc-lead area, Claiborne and Union Counties, east Tennessee, by D. F. Kent and John Rodgers, 4 pp. , 1 map, 1945.

The Mosheim anticline area, Green County, Tennessee, by D. F. Kent and T. C. Dunlap, 3 pp. 2 maps, 1945.

The Ritchie zinc prospect, Claiborne County, Tennessee, by V. E. Nelson and Irvin Gladstone, Strategic Minerais Investigations Preliminary Map 3-200, 3 pp. , 2 maps, 1946.

*The Bunch Hollow zinc and lead mine, Claiborne County, Tennessee, by D. F. Kent, Strategic Minerals Investigations Preliminary Map 3-201, 4 pp. , 1 map, 1946.

Geologic map with structure sections of the Mascot-Jefferson City, Tennessee, zinc mining district, by Josiah Bridge, 1946. $\$ 1.00$ from Tennessee Division of Geology, G-5 State Office Building, Nashville, Tennessee.

Hardwick mine area, Bradley County, Tennessee, by J. C. Dunlap and C. L. Jones, Strategic Minerals Investigations, Preliminary Map 3-185, 4 pp. , 1 map, 1946.

Geology of the Eve Mills zinc area, Monroe County, Tennessee, by J. C. Dunlap, Strategic Minerals Investigations. Preliminary Map 3-215, 2 pp. , 2 maps, 1947. 
Index

no.

Virginia

(225)

Wisconsin

(226).
The Arcadia zinc area, Scott County, Va., by Irvin Gladstone, V. E. Nelson, and D. F. Kent, 1 map, 1945.

Preliminary report on the general geology and ore deposits of the Mifflin-Cokerville area, Wis. , by A. F. Agnew and A. V. Heyl, Jr. , 5 pp., 1 map, 1944.

Zinc deposits of the Meekers Grove(Jenkinsville) area of the Wisconsin lead-zinc district, by A. V. Heyl, Jr., A. F. Agnew, and C. H. Behre, Jr., 1 map, 1945.

Zinc-lead deposits of the Hazel Green-Shullsburg area, Lafayette and Grant Counties, Wis., by A. F. Agnew, A. V. Heyl, Jr., C. H. Behre, Jr., and E. I. Lyons, Strategic Minerals Investigations Preliminary Map 3-216, 11 pp. , 2 maps, 1948.

Maps.

Maps of areas east of the Mississippi River can be ordered from the Chief of Distribution, U. S. Geological Survey, Washington 25, D. C. Maps of areas west of the Mississippi River can be ordered from the Distribution Section, U. S. Geological Survey, Denver Federal Center, Denver, Colorado.

Missouri Basin Studies

Index Map

no. no.

(229) 8 Map showing mineral deposits of Colorado; compiled by R. P. Fischer, Wilbur Burbank, Helen Cannon, and others. Scale, 1:1,000,000 ( 1 inch = nearly 16 miles). 1 sheet, $22 \times 32$ inches. $30 \mathrm{c}$.

(230) 13 Map showing metallic mineral deposits of South Dakota; compiled by R. P. Fischer. Scale, $1: 1,000,000$ ( 1 inch $=$ nearly 16 miles). 1 sheet, $20 \times 36$ inches. $25 \mathrm{c}$.

(231) 16 Map showing metallic mineral deposits of Montana; compiled by F. M. Chace, Fred Cater, Virginia Byers, and others. Scale, $1: 1,000,000$ ( 1 inch = nearly 16 miles). 1 sheet, $25 \times 45$ inches. $30 \mathrm{c}$.

17 Map showing metallic mineral deposits of Wyoming; compiled by R. P. Fischer and others. Scale, 1:1,000,000, ( 1 inch = nearly 16 miles). 1 sheet, $21 \times 30$ inches. $20 \mathrm{c}$.

(233) 18 Map showing metallic mineral deposits of Missouri; compiled by V. S. Neuschel and

E. T. McKnight. Scale, 1:1,000,000 (1 inch = nearly 16 miles). 1 sheet, $26 \times 40$ inches. 20c.

Tennessee River Basin

Index

no.

Tennessee River Basin mineral resources map. Scale, 1:500,000 ( 1 inch $=$ nearly 8 miles). $44 \times 64$ inches. $\$ 1$.

Mineral Investigations Field Studies

Index

no.

(235) MF 3. Geologic structure of the Beetown lead-zinc area, Grant County, Wis., by A. V. Heyl, .rr., E. J. Lyons, and J. J. Theiller, 1952. 40c.

Maps showing distribution of reserves of lead and zinc in the United States as of 1944, by districts. (From Mineral position of the United States, by the staffs of the Bureau of Mines and the Geological Survey. See no. 239 of bibliography.) Free on request to the U. S. Geological Survey, Washington $25, \mathrm{D}$. C.

\section{Miscellaneous publications}

Index

no.

\footnotetext{
*U. S. Geological exploration of the fortieth parallel, part III, Mining Industry, Geology of the White Pine district, Nevada, by Arnold Hague, 1870.

*World Atlas of Commercial Geology, part I. Distribution of mineral production, 72 pp. , 1921.
} 

E. F. Fitzhugh, Jr., E. T. McKnight, and A. L. Ransome, in Investigations of National Resources, prepared by combined staffs of Bureau of Mines and Geological Survey, published as part of hearings before National Resources Economic Subcommittee of the Committee on Public Lands of the Senate, pp. 254-258, 305-310.' Available from Superintendent of Documents, Government Printing Office, Washington 25, D. C. $\$ 1.75$ (unbound). Also available as Mineral Resources of the United States, Public Aff airs Press, 2153 Florida Ave., Washington 8, D. C. , 1948. \$5. (bound). Copies of map showing distribution of lead and zinc reserves in the United States is available on request to the U. S. Geological Survey, Washington 25, D. C. Publications of the Geological Survey, May 1948. Fourth supplement, May 1952. Consult State and subject index to determine what reports may be available on specific areas or commodities, as these reports often contain additional information on the occurrence of lead and zinc ores. Free on request from U. S. Geological Survey, Washington 25, D. C. Bibliography of North American Geology, published as the following U. S. Geological Survey Bulletins:

$\begin{array}{llll}747 & (1785-1918) & 952 & (1944-1945) \\ 823 & (1919-1928) & 958 & (1946-1947) \\ 937 & (1929-1939) & 968 & (1948) \\ 938 & (1940-1941) & 977 & (1949) \\ 949 & (1942-1943) & 985 & (1950)\end{array}$


Alaska, general................. 60 Berg Bas1n, Wrangell district...... 162 Glacler Bay, Wrangell distr1ct..... 204 Groundhog Bas1n, Wrangell district.. 199 Ketchiken district........... 48, 124 Lake cla1ms, Wrangell district..... 201 Lucky Boy claims, Prince of

Wales Island.................. 203 Moth Bay, Rev1llagigedo Island...... 200 Mount Elelson district........ 104, 202 Nixon Fork country............... 94 Ruby......................... 94 Southeastern...... 48, 87, 96, 120, 124 $162,199,201,203,204$ Tracy Arm, Petersburg district...... 124 Wales district................. 124 Wrangell district..... 48, $87,124,162$ $199,201,204$

Arizona, Aravaipa district, Graham

County..................... 88

Banner district, Gila County........ 90 Bigbug district (Iron King mine), Yavapai County................. 163 Bisbee, Coch1se County............. 145 Black Mountains, Mohave County... 47, 52 Boulder (Hoover) Dam reglon, Coconino, Mericopa, and Mohave Counties....................... 109 Bradshaw Mounta1ns, Yavapa1 County.. 93 Cerbat Range, Mohave County...47, 52, 123 Coch1se County.................. 1, 145 Coconino County.................. 109

Gila County.................. 90

Graham County................... •88

Grand Wash Cliffs, Mohave

County.................47, 52

Humboldt region, Yavapal County..... 163 Jerome quadrangle, Yavapa1 County... 93 Kofa Mounta1ns, Yuma County........ 73

Maricope County................. 109

Mohave County......... 47, 52, 109, 123

Patagonla Mountains, Santa

Cruz County................. 70

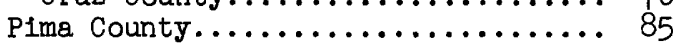

Pinal County............990, 154, 205

Ray district, Pinal County......... 154

Reward area, Pinal County......... 205

Seddle Mountain district,

Pinal County................ 90

Santa Cruz County............... 70

Santa Rita Mountains, Santa Cruz

County..................... 70

Sierrita Mountains, Pima County..... 85

Stanley district, Graham County..... 88

Wallapa1 district, Mohave County.... 123

Yavapa1 County............ 93, 163

Yuma County............... 57, 73

Arkansas, Caddo Gap quadrangle......... 97

De Queen quadrangle.............. 97

Eureka Springs-Harrison

quadrangle................... 153

Northern Arkansas........... 2, 40, 105

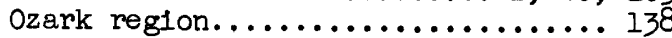

California, Carbonate King mine,

San Bernardino County............. 206
California--Continued

Derwin district, Inyo County........ 69 Inyo Range............. 18, 67, 69, 164 Koko Weef Mountain area,

San Bernandino County............ 206 Lippincott area, Inyo County........ 164 Sierra Nevada.................. 18 White, Mountains, Inyo County....... 67

Colombia, Antioquia............... 121

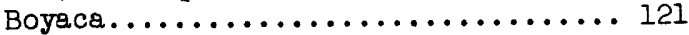
Caldas......................... 121

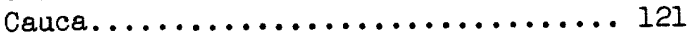
Cundinamarca..................... 121

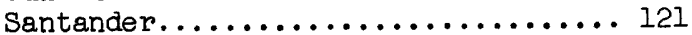

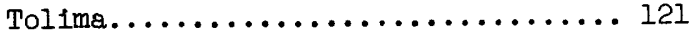

Colorado, general................ 20, 229 Aspen district, Pitkin

County............... 20, 95, 129 Bonanza district, Saguache County.... 25 Boulder County............. 14, 20, 37 Breckenridge district, Sumit

County.............. 10, 20, 28, 37 Chaffee county............... 20, 36, 172 Clear Creek County....... 14, 20, 37, 166 Creede district, Mineral

County............... 65, 84, 98

Custer County............. 20, 69, 134 Dolores County........... 20, 135, 138 $147,169,208$

Eagle County................ 20, 165 Emplre district, Clear Creek

County............... 7, 14, 37

Front Range.................. 20, 37

Garfield quadrangle, Chaffee and

Gunnison Counties.............. 172

Georgetown district, Clear

Creek County........7, 14, 20, 37, 43 G1lp1n County........... 14, 20, 37, 73

Gunnison County........... 20, 110, 172 Hinsdale County...............20, 59 Kokomo (Tenmile) district,

Summit County............ 167, 168, 170 Lake City area, Hinsdale

County..................... 59

Lake County............................ $22,46,81$ $91,127,132,171,207$

La Plata district, Chaffee County.... 36 Leadville district, Lake

County............. 20, 22, 46, 81 91, 127, 132, 171, 207

London Fault area, Park County...... 115 Mineral County.......... 20, 65, 84, 98 Minturn quadrangle, Eagle

County...................... 165

Montezuma quadrangle, Summit

County....................29, 37

Mosquito Range, Lake County......... 207 Ouray County............. 20, 114, 209 Park County................... 20, 115 Pitkin County............. 20, 95, 129 Rico Mountains,

Dolores County.......... 138, 147, 208 Saguache County.............. 20, 25 San Juan County. . . . . . . . . . . . . 20, 39 $135,146,169$ San Miguel County......... 20, 135, 169 
Colorado--Continued

Silver Plume district,

Clear Creek County............. 166

Silverton quadrangle, San Juan

County.................. 39, 146

Snowmass Mountain area,

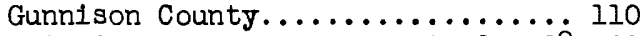

Summit County.......... 10, 20, 28, 29 $37,122,167,168,170$

Telluride quadrangle, Dolores,

San Juan, and San Miguel

Counties.................. 135, 169

Uncompahgre district,

Ouray County............... 114, 209

Upper.Blue River area,

Summit County............... 122

Geochem1stry.......8 89, 157, 158, 161, 161a

Idaho, general................. 100

Bear River Range............23, 58

Blaine County.........6 67, 69, 99, 137

Bolse Basin.................. 118

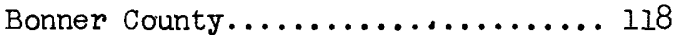

Casto quadrangle,

Custer County................. 106

Clark Fork district,

Bonner County............... 118

Coeur d'Alene region,

Shoshone County.....6, 43, 173, 161a

Custer County............ 16, 65, 66

De Lamar district, $69,99,106,137$ Owyhee County................ 137

Dome district, Blaine County....... 67

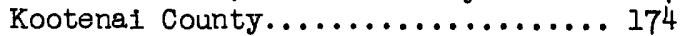

Lemh1 County................. 63

Loon Creek district,

Custer County............... 65

Mackay region, Custer County....... 16

Mullan quadrangle, Shoshone

County..............67, 175, 177

Northern Idaho.............. 44, 50

Owyhee County.................. 137

Pine Creek district, Coeur d'Alene region, Shoshone County......83, 173

Pottsville quadrangle,

Shoshone County........... 175, 176

St. Joe River Basin............... 44

Sawtooth quadrangle, Blaine and

Custer counties............... 69

Shoshone County.....6, 43, 67, 86, 173 $175,176,177,210,211$

Silver City district,

Owyhee County................. 137

Southeastern Idaho............... 23

Twin Crags area, Kootena1

County....................... 174

Wood River region, Blaine and

Custer Counties............99, 137

Illinols, general............ 41, 42, 45

Galena-Ellzabeth quadrangle....... 152

Lancaster-Mineral Point

quadrangle.................... 148

Upper Mississippi Valley......... 45

Iowa, Center Grove-Plkes Peak area,

Dubuque County................... 212
Iowa--Continued

Galena-Elizabeth quadrangle........ 152

Lancaster-Mineral Point

quadrangle.................. 148

Tete des Morts area.............. 178

Upper Mississippi Valley.......... 45

Kansas, Plcher Fleld, Cherokee County...... 216 Tri-State (Joplin) district..........40, 72, 149, 216

Kentucky, western Kentucky....... 4, 40, 234

Maine, general.................. 55

Microscopic determination....... 101, 103, 116

Missouri, general................. 233

Southeastern Missour1............ 38

Tri-State (Joplin)

district..........40,72, 149, 186

Wyandotte quadrangle,

Tri-State district............ 186

Montana, general.................. 231 Barker district, Cascade County..... 137

Bearpaw Mountains............... 54

Butte district, Silver Bow County.... 9

Cooke City district, Park County..... 98

Dunkleberg district, Granite

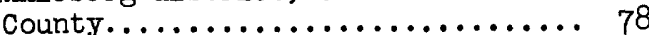

Elkhorn district, Jefferson

County..................... 138

Elkhorn Mountains................ 58

Helena region, Jefferson,

Broadwater, Lewis and Clark, and

Powell Count1es..............62, 102

Libby quadrangle, Lincoln and

Sanders Counties............... 119

Little Belt Mountains........... 137, 141

Melrose, Silver Bow County......... 92

Neihart district, Cascade

County........................ 137

New World district,

Park County................... 98

Northwestern Montana........... 44, 50

Saltese district, Mineral

County................... 67

Silver Bow County..............9, 92

Yogo district, Fergus County........ 137

Nevada, Antler Peak quadrangle,

Humboldt and Lander Counties.......... 179

Arabia district, Pershing County..... 78

Boulder (Hoover) Dam region,

Clark, Lincoln, Nye, and

Esmeralda Counties............... 109

Cedar Mountain, Mineral County....... 85

Clark County... 24, 44, 67, 109, 114, 180

Eastern Nevada................ 77

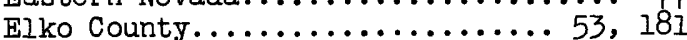

Ely district, White Pine County..... 15

Eureka County........53, 126, 128, 133

Eureka district,

Eureka County.......... 126, 128, 133

Goodsprings quadrangle,

Clark County.................. 24

Green Monster mine, Yellow Pine

district, Clark County........... 180

Lander County............... 53, 179 
Nevada--Continued

Ilincoln County............... 26, 109

Ploche district, IIncoln

County..................... 26

Potosi mine, Clerk County......... 44

Rip Van Winkle mine, Merrimac

district, Elko County........... 181

Searchlight district,

Clark County................. 114

White Pine County........... 15, 237

White Pine district, White

Pine County.................. 237

Yellow Pine district,

Clark County............67, 180

New Hampshire, Milan mine,

Coos County...................... 55

New Jersey, Frankin,

Sussex County............. 31, 40, 150

Sterling Hill, Sussex County...... 31

New Mexico; general.............. 8, 44 Bayard area, Central district,

Grant County................. 108

Carlisle area, Steeple Rock

district, Grant County..........2 213

Central district, Grant County...... 108

Grant County............ 35, 58, 107 $108,183,213$

Hidalgo County............. 35, 111

Little Hatchet Mountains,

Hidalgo and Grant Counties....... 35

Lordsburg district, Hidalgo

Cownty..................... 111

Magdalena district.

Socorro County................ 32

New Placers district, (San Pedro and Carnahan mines) Santa $\mathrm{Fe}$

County......................... 184

North area, Cerrillos district,

Santa Fe County................214

Organ district, Dona Ana County..... 182

Pinos Altos district,

Grant County................ 58

Royal John area, Swartz district,

Grant County................ 183

Sante Fe County............. 184, 214

Santa Rita area, Grant County....... 107

Tres Hermanas district,

Luna County................ 49

New York, Shawangunk mine,

Sullivan County................... 123

West Branch area, Gouverneur

district, St. Lawrence County..... 215

North Carolina, Gaffney-Kings Mountain

quadrangle....................... 156

Redmond mine, Haywood County........ 185

Oklahoma, Picher field,

Ottawa County................... 216

Tri-State (Joplin)

district......... 47, 72, 186, 216

Wyandotte quadrangle,

Tri-State district............ 186

Oregon, Cascade Range
Pennsylvania, Honeybrook quadrangle,

Chester County................... 112 Phoenixville quadrangle,

Chester County................ 112

Reserves..................... 71, 236

Secondary enrichment of ores.......64, 75

South Carolina, Gaffney-Kings Mountain

quadrangle....................... 156

South Dakota, Black Hills....... 3, 155, 230

Southern Appalachian region........ 30, 234

Technology........................ 159

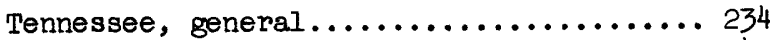

Bristol quadrangle................ 142

Bunch Hollow mine,

Claiborne County...............221

Clatborne County.......... 218, 220, 221

Cleveland quadrangle.............. 139

Copper Ridge district,

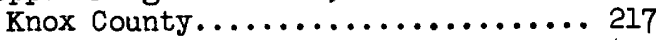

Ducktown district.............21, 30

East Tennessee............ 41, 159, 234

Eve Mills area, Monroe

County.................... 188, 224

Hardw1ck area, Bradley County........223

Mascot-Jefferson City area,

Jefferson County............... 222

Maynardville quadranglie............. 144

Morristown quadrangle............ 140

Mosheim anticline area,

Greene County................... 219

Powell River area, Claiborne and

Union Counties.................218

Ritchie prospect, Claiborne

County....................... 220

Stiner prospect, Union County....... 187

Union County............... 187, 218

Texas, Llano-Burnet region......... 56, 151 Shafter district, Presidio

County.................. 117, 189

Thalland........................... 125

United States, general.... 43, 51, 61, 74, 79 $130,131,236,238,239,240,241$

Utah, general..................... 19

Apex mine, Washington County........ 190

Bear River Range.............. 58

Beaver Lake district,

Beaver County............... 12

Bingham district, Salt Lake and

Tooele Counties.............. 5, 40

Canyon Range................... 13

Cottonwood-American Fork area,

Salt Lake and Utah Counties..... 33, 73

Falrfield quadrangle, Salt Lake,

Tocele, and Utah Counties........ 27

Ophir district, Tooele

County..................... 82

Park City district, Sumit

County.................. 11, 41 
Utah--Continued

Paymaster mine, Washington

County..................... 190

Promontory district,

Boxelder County............... 76

Salt Lake County...... 5, 27, 33, 40, 73

San Francisco district,

Beaver County................ 12

Star district, Beaver County....... 12

Stockton quadrangle,

Tooele County............... 27

Tintic district, Juab and

Utah Count1es..........17, 136, 143

Tooele County.......... 5, 27, 40, 82

Utah County.... 17, 27, 33, 73, 136, 143

Virginia, general................... 234

Arcad1a area, Scott County......... 225

Bristol quadrangle.............. 142

Washington, Bechtol mine, Northport

district, Stevens County............... 195

Carbo prospect, Northport

district, Stevens County......... 193

Colville Indian Reservation....... 80

Conconully district,

Okanogan County.............. 76

Lead Hill area, Metaline district, Pend Orellle County............. 191

Mataline district, Pend

Ore111e County....... 34, 58, 191, 192

Monte Cristo district,

Snohomish County.............. 138

Northeastern Washington........... 68

Northport district,

Stevens County.

193, 194, 195
Washington--Continued

Republic district,

Ferry County.................. 68

Ruby district, Okanogan

County.....................76

Tom Cat and Hanley prospects,

Metaline district, Pend Oreille

County........................ 192

Wisconsin, Beetown area,

Grant County.................. 197, 235

Dodgeville, Iowa

County.................... 43

Grant County............43, 45, 160

$196,197,226,228,235$

Hazel Green-Shullsburg area, Lafayette and Grant

Counties..................... 228

Highland area, Iowa County......... 198

Iowa County...... 43, 45, 160, 196, 198

Lafayette County.............43,45

Lancaster-Mineral Point $160,196,227,228$

quadrangle................... 148

Meekers Grove area,

Lafayette County. . . . . . . . . . . . . . 227

Mifflin-Cokerville area,

Grant County.................... 226

Prairle du Chien group.............. 160

Upper M1ss1ss1pp1 Valley........43, 45

160,196

World resources............ 130, 131, 238

Wyoming, general................... 232 


\section{AUTHOR INDEX}

Adams, G. I. ................ 2, 40, 138 Addison, C. C. .................. 216 Agnew, A. F. ... 160, 178, 212, 226, 227, 228

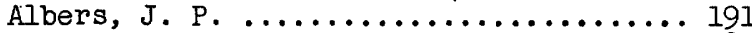

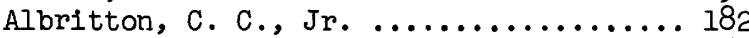

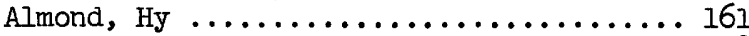

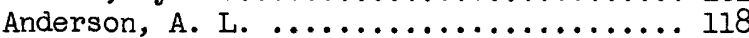

Bain, H. F. .......41, 42, 43, 44, 45, 138

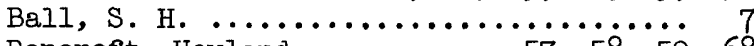
Bancroft, Howland .........57, 58, 59, 68 Barclay, 'M. G. ................... 209 Barrel1, Joseph ................. 138

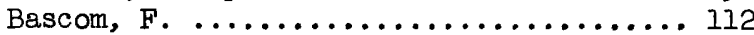
Bastin, E. S. ................. 14, 73 Behre, C. H., Jr. ....... 207, 212, 227, 228

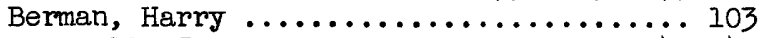
Boutwell, J. M. .......... 5, 11, 40, 41

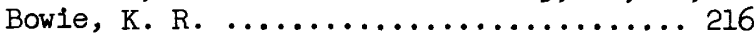

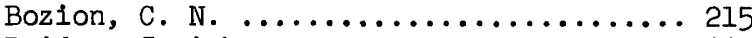

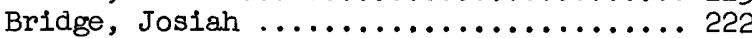
Brock, M. R. .................. 172 Brokaw, A. L. .............. 180, 206 Brooks, A. H. .................. 60

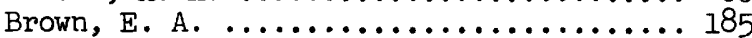

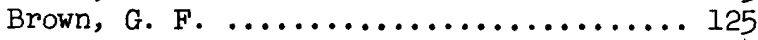

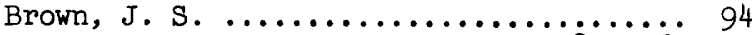
Buddington, A. F. ...........87, 96, 113 Burbank, W. S. .......... 25, 114, 209, 229 Burchard, E. F. ...............2, 148 Butler, B. S. ...... 12, 19, 33, 73, 76, 115 Byers, Virginia .......................

Calkins, F. C. .......... 6, 33, 50, 67 Callaghan, Eugene ........... 109, 113, 114 Campbel1, C. D. .......... 192, 193, 194, 195 Campbell, M. R..................... 142 Cannon, Helen ...................... 229

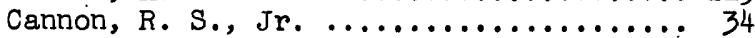

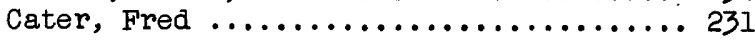
Chese, F. M. .................. 231

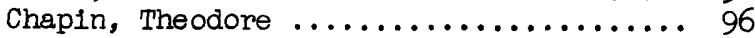
Clarke, F. W. ................... 89

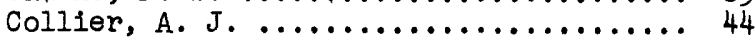

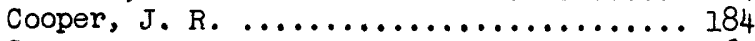

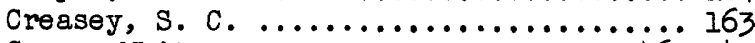
Cross, wh1tman .............. 146, 147

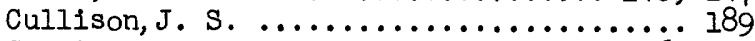
Curtis, J. S. ............... 126, 133

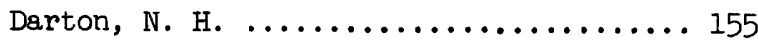
Dings, M. G. ............... 123, 172

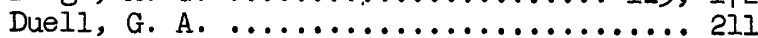
Dunlap, J. C. ......... 188, 219, 223, 224

Eckel, E. B. ................. 36

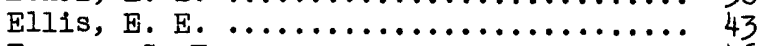
Emmons, S. F. ............ 3, 5, 22, 46 $127,132,134,143$ Emmons, W. H. ....21, 53, 55, 64, 65, 75, 84

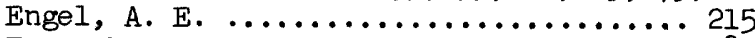

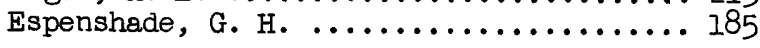

Farwell, F. W. .................. 184

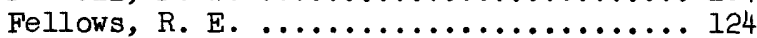
Fischer, R. P. ........ 216, 229, 230, 232 Fitzhugh, E. F., Jr. ............... 239

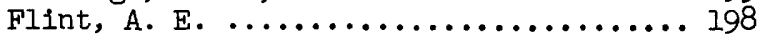

Flint, G. M., Jr. .......... 124, 201, 204

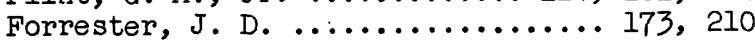

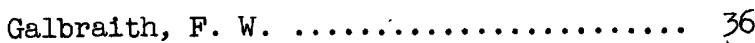

Garrey, G. H. ............... 7, 43 Gates, G. 0. ................. 120, 202 Gault, H. R. .......... 124, 199, 201, 204 Gibson, Russell .................. 119

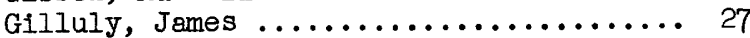
Girty, G. H. ................. 23 Gladstone, Irvin ....... 187, 192, 220, 225 Goddard, E. N. ............ 37, 166, 207

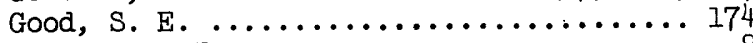
Gordon, C. H. ................. 8

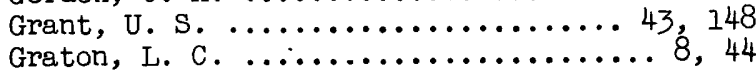
Griggs, A. B. .............. 175, 177

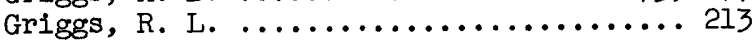

Hadley, J. B. ................... 205 Hague, Arnold ................ 128, 237

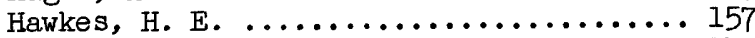

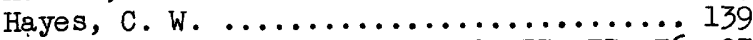
Heikes, V. C. .......17, 19, 33, 73, 76, 93 Henderson, C. W. ................ 20, 25 Hewett, D. F. .............. 24, 99, 109 Heyl, A. V., Jr. ........... 160, 196, 197 $212,226,227,228,235$ Hill, J. M. ....... 14, 61, 67, 70, 73, 77

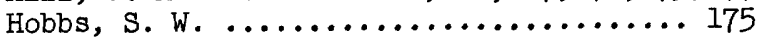

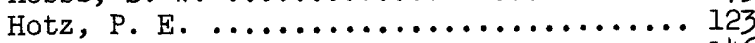

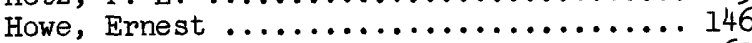

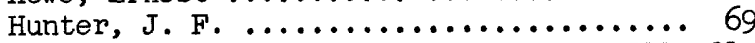
Hutchinson, R. M. .............211, 217

Irving, J. D. ............ 3, 22, 46, 59

Jagger, T. A., Jr. .............. James, H. L. . ...................... 19 I

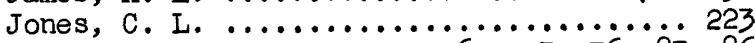
Jones, E. L., Jr. ......67, 73, $76,83,86$

Keith, Arthur ..... 5, 21, 41, 140, 144, 156 Kennedy, V. C. .................. 16la Kent, D. F. .............. 159, 187, 217 $218,219,221,225$

K1nkel, A. R., Jr. ............... 190 Kinney, D. M. .................. 183

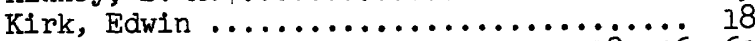
Knopf, Adolph $\ldots \ldots \ldots \ldots \ldots \ldots \ldots \ldots$ is, 26,62 $67,69,78,85,95$ Koschmann, A. H. ........ 32, 167, 168, 170

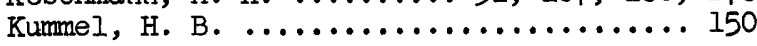

Lak1n, H. W. ................ 158, 161

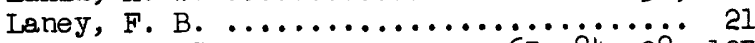
Larsen, E. S. ............ $65,84,98,103$ Lasky, s. G. ................ 35, 108, 111

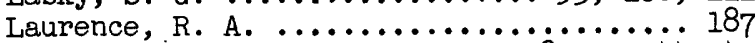
Lindgren, Waldemar .........8, $17,44,49$ $51,68,93,137$ Loughlin, G. F. ..........13, 17, 19, 22 $32,73,81,82,91$ Lovering, T. S. .... 28, 29, 37, 98, 165, 181 Lyons, E. J. ........ 160, 197, 212, 228, 235

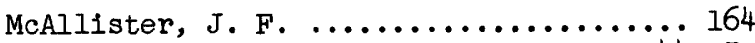
MacDonald, D. F. .............. 44, 50 
McKnight, E. T. ....... 105, 216, 233, 239

Mansfield, G. R ................ 23

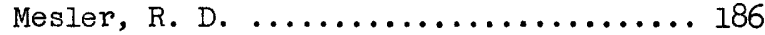

Miser, H. D. ..............97, 153

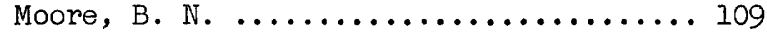

Nelson, V. E. .............. 173, 182 $187,211,220,225$

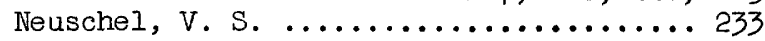

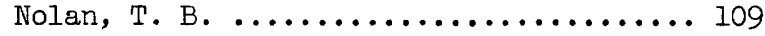

Owens, M. F., Jr. ................216

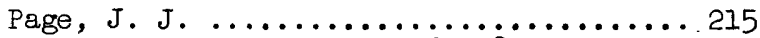
Paige, Sidney ........56, 58, 107, 151, 155 Palache, Charles ..................... 150 Pardee, J. T. ........... 78, 80, 92, 102

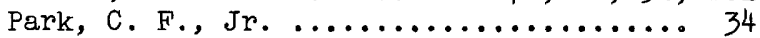
Pepperburg, L. J. ............... 54

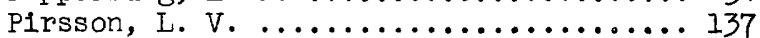
Purdue, A. H. ..............2, 97, 153

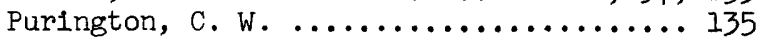

Ransome, A. L. ................... 239 Ransome, F. L. ........ 1, 6, 10, 39, 43, 85 $138,145,146,147,154$ Ray, R. G. .................. 124, 162 Reed, J. C. .................. 104, 120

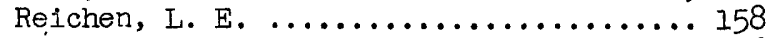

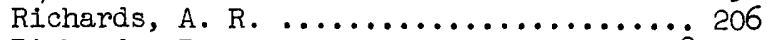
Richards, R. W. ............... 58, 92

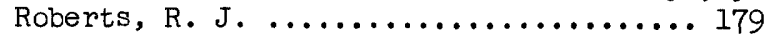

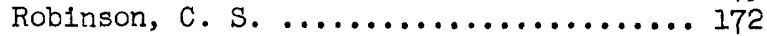

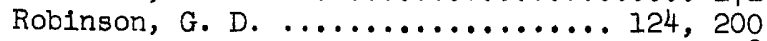
Rodgers, John ............... 217, 218 Ross, C. P. ...... 88, 90, 99, 100, 106, 117 Ross, C. S. .................... 30 Rossman, D. L. ................. 124, 204

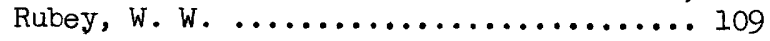

Salisbury, R. D. ................. 150 Sandburg, A. E. .................. 207

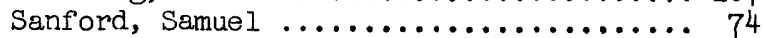
Schaller, W. T. .................. 109 Schrader, F. C. .......47, 52, 70, 74, 102

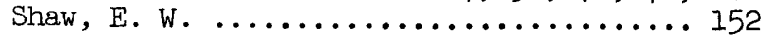
Short, M. N. ...............101, 116
Siebenthal, C. E. ..47, 72, 79, 130, 149, 186

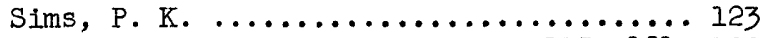
Singewald, Q. D. ........... 115, 121, 122 Smith, G. 0.............71, 136, 143 Smith, J. F., Jr. ............ 184, 211 Smith, W. S. T. .............4, 40, 149 Spencer, A. C. ............. 15, 107, 150 Spurr, J. E. ........... 7, 43, 129, 138

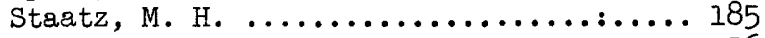

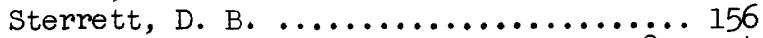

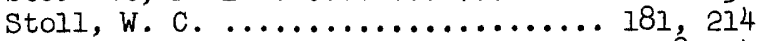
Stone, R. W. ................ 58, 74

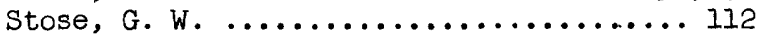
Sullwold, H. H., Jr. .............. 205

Theiler, J. J. .............. 197, 235

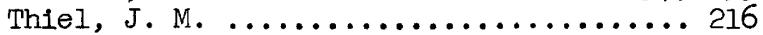

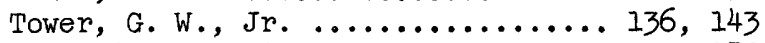

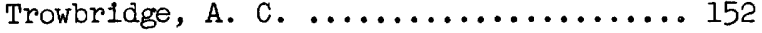

Twenhofel, W. S. ............... 120, 203

Tweto, o. I. ................ 165, 171

Ulrich, E. 0. ............... 2, 4 Umpleby, J. B. ..............16, 63, 65 $66,67,69,86,99$

Vanderwilt, J. W. ..................110

Van Hise, C. R. ................. 138

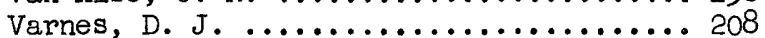

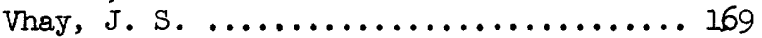

Wadsworth, A. H., Jr. .......... 184, 208

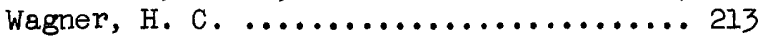
Wahrhaftig, Clyde ................. 202 Wallace, R. E. .............. 175, 176 Ward, F. N. .......................... 161 Weed, W. H. ............ 9, 137, 138, 141 We1ssenborn, A. E. .............. 184, 189 Wells, F. G. ................ 167, 216 Westgate, I. G. .............26, 99

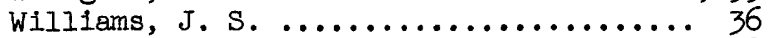

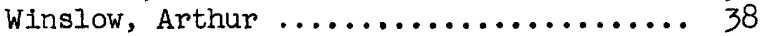

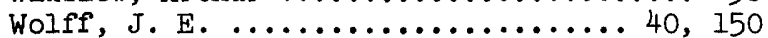

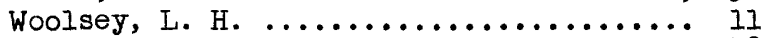

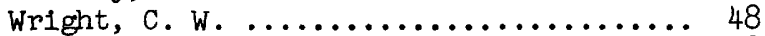
Wright, F. E. ................. 48 


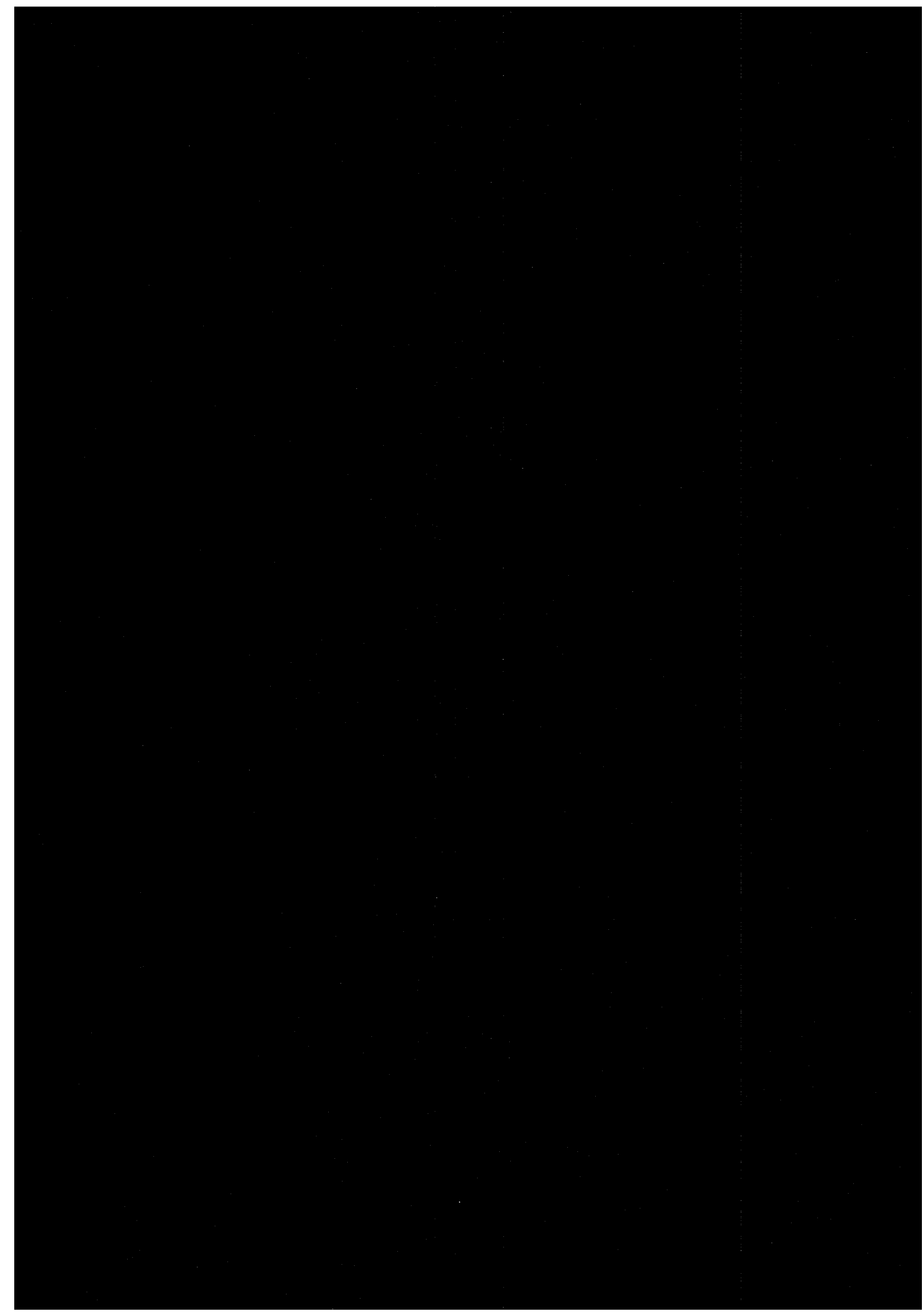




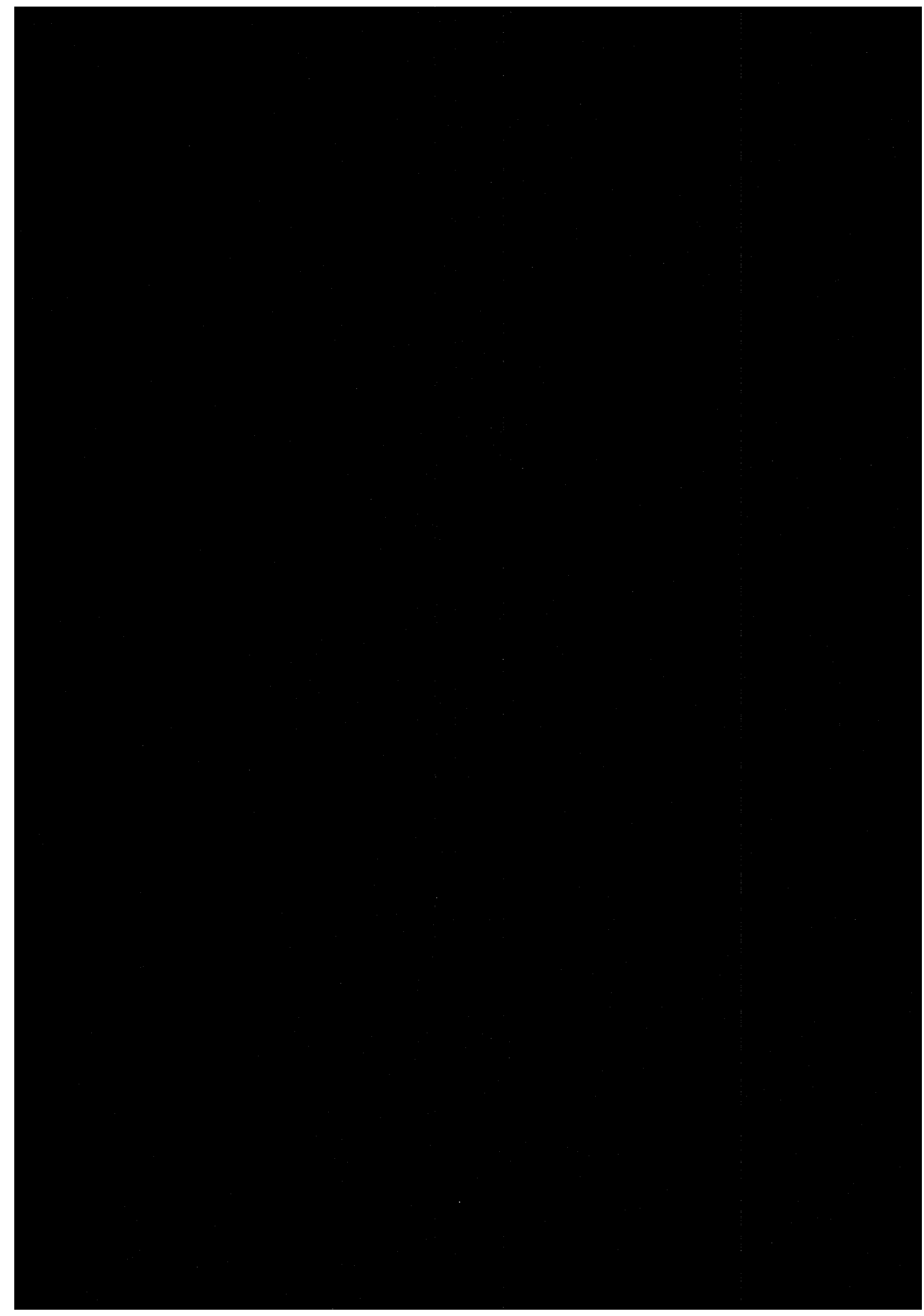

